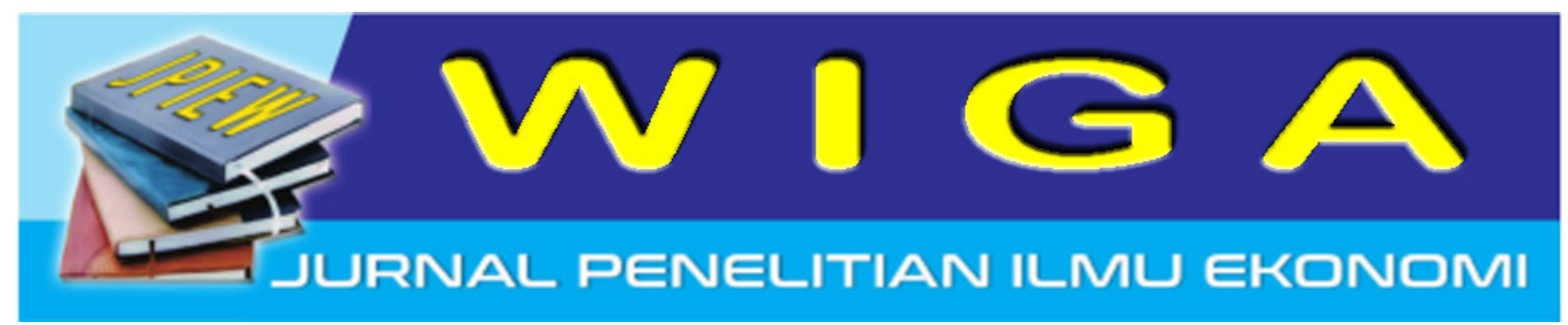

\title{
PENGENDALIAN KUALITAS DENGAN MENGGUNAKAN METODE STATISTICAL QUALITY CONTROL (SQC) UNTUK MEMINIMUMKAN PRODUK GAGAL PADA TOKO ROTI BAROKAH BAKERY
}

\author{
Muhammad Syarif Hidayatullah Elmas \\ Prodi Manajemen Fakultas Ekonomi UPM Probolinggo \\ syarif.upm@gmail.com
}

\begin{abstract}
Abstrak
Quality Control adalah suatu kegiatan (manajemen perusahaan) untuk mempertahankan dan arahkan ke kualitas produk (dan) jasa perusahaan dapat dipertahankan seperti yang direncanakan. Quality Control yang digunakan perusahaan untuk meminimalkan produk gagal menggunakan metode statistik Quality Control (SQC) sehingga perusahaan dapat memenuhi kualitas produk yang telah ditetapkan perusahaan dan konsumen puas dalam mengkonsumsi produk. Tujuan yang akan dicapai dalam penelitian ini adalah untuk menentukan metode statistik Quality Control (SQC) dengan peta kendali tekhnik dan diagram sebab dan akibat diterapkan perusahaan Bakery Barokah Bakery dalam kontrol kualitas untuk meminimalkan produk gagal. pengumpulan data tekhnik yang digunakan adalah penelitian dan penelitian lapangan perpustakaan, sedangkan alat analisis data yang digunakan diagram kontrol dan diagram sebab dan akibat. Hasil analisis diagram kontrol menunjukkan bahwa jumlah produk yang diperiksa sebanyak 27,710 unit, rata-rata 0.099 kerusakan produk atau 9,9\%. Keterbatasan: pengawasan UCL dari 0,1161 atau $11,61 \%$, LCL dari 0,0819 atau 8,12\%. kontrol kualitas pada Bakery Barokah Bakery baik karena jumlah produk yang gagal masih dalam batas-batas wajar terletak antara UCL dan LCL. Sedangkan hasil dari diagram untuk hasil (tulang ikan), faktor utama penyebab kegagalan produk roti di toko roti Barokah Bakery faktor yaitu manusia. Di mana orang gagal dalam pembuatan produk roti. Jadi diperlukan pelatihan untuk meminimalkan produk gagal yang terjadi disebabkan oleh faktor manusia.
\end{abstract}

Kata Kunci: pengendalian kualitas dan Pengendalian Kualitas Statistik (SQC

\begin{abstract}
Quality Control is an activity (company management) to maintain and navigate to product quality (and) services companies can be maintained as planned. Quality Control used the company to minimize failed products using methods of Statistical Quality Control (SQC) so that the company can meet the quality products that have been specified businesses and consumers are satisfied in consuming the product. The purpose of that will be achieved in this research is to determine the method of Statistical Quality Control (SQC) with tekhnik control chart and diagram of cause and effect applied the company Bakery Barokah Bakery in quality control to minimize the product failed. Tekhnik data collection that is used is a library research and field research, while data analysis tool that is used control chart and diagram of cause and effect. The results of the analysis of control charts shows that the number of products that are examined as much as 27.710 units, the average of 0,099 product damage or $9.9 \%$. Limitations: UCL supervision of 0,1161 or $11.61 \%$, LCL of 0,0819 or $8,12 \%$. Quality control on the Bakery Barokah Bakery is good because the number of failed products are still within the boundaries of fair is located between UCL and LCL. While the results from the diagram for result (fish bones), the main factor the causes of the failure of the products of bread in the Bakery Barokah Bakery namely human factors. Where people fail in the making of the bread products. So required training to minimize failed products that occurred caused by human factors.
\end{abstract}

Key Words : quality control and Statistical Quality Control (SQC) 


\section{PENDAHULUAN}

Pengendalian kualitas harus dapat mengarahkan kepada beberapa tujuan secaraterpadu, sehingga para konsumen dapat puas mempergunakan produk atau jasa dari perusahaan. Harga produk atau jasa perusahaan tersebut harus dapat ditekan serendah-rendahnya serta proses produksinya dapat selesai sesuai dengan waktu yang telah direncanakan sebelumnya didalam perusahaan yang bersangkutan. Pengendalian kualitas merupakan suatu kegiatan yang sering dilakukan disetiap perusahaan. Apabila pengendalian kualitas dilakukan dengan baik, bagi perusahaan akan menimbulkan tambahan biaya yaitu biaya pengawasan kualitas, dan tingkat kerusakan produk yang dihasilkan sangat rendah atau produk rusak yang terjadi sedikit.

Sebaliknya bagi perusahaan yang tidak memperhatikan pengendalian kualitas, dalam jangka pendek perusahaan tidak perlu mengeluarkan biaya pengawasan kualitas, tetapi dalam jangka panjang perusahan sulit memasarkan produk dikarenakan tersaingiperusahaan yang sejenis yang kualitas produknya lebih baik serta jumlah produk rusak semakin banyak. Usaha pengendalian kualitas merupakan usaha preverentif (penjagaan) dan dilaksanakan sebelum kesalahan kualitas produk atau jasa tersebut terjadi, melainkan mengarahkan agar kesalahan kualitas tersebut tidak terjadi didalam perusahaan yang bersangkutan.

Toko Roti Barokah Bakery telah melakukan pengendalian kualitas terhadap produk yang mereka produksi, namun masih terdapat produk gagal yang dihasilkan oleh perusahaan tersebut. Padahal produk gagal berpengaruh pada keuntungan yang diperoleh perusahaan dikarenakan biaya yang dikeluarkan meningkat. Untuk itu perlu adanya pengendalian kualitas dengan metode Statistical Quality Control (SQC) supaya hasil produksi yang diperoleh mengalami sedikit produk yang gagal.

Menurut

Ahyari

(2000:239),

pengendalian kualitas adalah merupakan suatu aktivitas (manajemen perusahaan) untuk menjaga dan mengarahkan agar kualitas produk (dan jasa) perusahaan dapat dipertahankan sebagaimana yang telah direncanakan.Sedangkan Statistical Quality Control (SQC) menurut Assauri (2004;219), "Adalah suatu sistem yang dikembangkan untuk menjaga standar yang uniform dari kualitas hasil produksi, pada tingkat biaya yang minimum dan merupakan bantuan untuk mencapai efisiensi".

Oleh karena itu, untuk menekan tingkat kerusakan produk dan mempertahankan kualitas produk di Toko Barokah Bakery maka peneliti merumuskan masalah yaitu analisis pengendalian kualitas dengan menggunakan metode Statistical Quality Control (SQC) untuk meminimumkan produk gagal pada Toko Roti Barokah Bakery.

Berdasarkan uraian di atas maka tujuan yang akan di capai pada penelitian ini adalah menentukan metode Statistical Quality Control (SQC) dengan tekhnik control chart dan diagram sebab akibat yang diterapkan perusahaan Toko Roti Barokah Bakery dalam mengendalikan kualitas untuk meminimumkan produk gagal.

\section{TELAAH PUSTAKA}

Pengertian dan konsep kualitas memiliki arti yang sangat luas, sehingga terdapat berbagai definisi atas kualitas. Menurut para ahli salah satunya, Ahyari (2000:239), "Kualitas didefinisikan sebagai jumlah dari atribut atau sifat-sifat sebagaimana dideskripsikan di dalam produk (dari jasa) yang bersangkutan". Pengendalian kualitas adalah merupakan suatu aktivitas (manajemen perusahaan) untuk menjaga dan mengarahkan agar kualitas produk (dan jasa) perusahaan dapat dipertahankan sebagaimana yang telah direncanakan.

Pengendalian kualitas memiliki beberapa faktor yang dipengaruhi yang dilakukan oleh perusahaan, meliputi :

1) Kemampuan proses. Batas-batas yang ingin dicapaiharuslah disesuaikan dengan kemampuan prosesyang ada. Tidak ada gunanya mengendalikan suatuproses dalam batas-batas yang melebihi kemampuanatau kesanggupan proses yang ada.

2) Spesifikasi yang berlaku, hasil produksi yang ingindicapai harus dapat berlaku, bila ditinjau dari segikemampuan proses dan keinginan atau kebutuhankonsumen yang ingin dicapai dari hasi lproduksitersebut. Dapat dipastikan dahulu apakah spesifikasitersebut dapa tberlaku sebelum pengendaliankualitas pada proses dapat dimulai.

3) Tingkat ketidak sesuaian yang dapat diterima. Tujuan dilakukan pengendalian 
suatu proses adalah dapat mengurangi produk yang berada di bawah standar seminimal mungkin. Tingkat pengendalian yang diberlakukan tergantung pada banyaknya produk yang berada dibawah standar

4) Biaya kualitas, sangat mempengaruhi tingkat pengendalian dalam menghasilkan produk dimana biaya mempunyai hubungan yang positif dengan terciptanya produk yang berkualitas.

Tujuan pengendalian kualitas adalah terdapatnya peningkatan kepuasan konsumen, proses produksi dapat dilaksanakan dengan biaya serendah-rendahnyaserta selesai sesuai dengan waktu yang telah ditetapkan

Dalam melakukan pengendalian kualitas, perusahaan menggunakan metode yang disebut pengendalian kualitas statistik atau statistical quality control. Menurut Yamit (2013:202), pengendalian kualitas statistik (statistical quality control) adalah alat yang sangat berguna dalam membuat produk sesuai dengan spesifikasi sejak dari awal proses hingga akhir proses. Dan terdapat pengertian lain yaitu menurut Assauri (2004;219) mengemukakan bahwa pengertian dari Statistical Quality Control (SQC) sebagai berikut : "Statistical Quality Control (SQC) adalah suatu sistem yang dikembangkan untuk menjaga standar yang uniform dari kualitas hasil produksi, pada tingkat biaya yang minimum dan merupakan bantuan untuk mencapai efisiensi".

Metode SQC terdapat 2 cara yaitu dengan menggunakan peta kendali (control chart) dan diagram tulang ikan (fishbone chart). Menurut Russell dan Taylor (2006:178) peta kendali (control chart) didefinisikan sebagai : "Control chart is a graph that establishes the control limits of a process." Penulis mengartikan: Peta kendali merupakan grafik yang mencerminkan batas kendali suatu proses. Sedangkan, pengertian peta kendali (control chart) menurut adalah : "Control chart are an outstanding techniques for problem solving and the resulting quality improvement.". Peta kendali adalah teknik yang dikenal untuk memecahkan masalah dan menghasilkan perbaikan kualitas.

Peta kendali $p$ yang digunakan ini memiliki manfaat untuk membantu pengawasan atau pengendalian proses produksi, sehingga dapat memberikan informasi mengenai kapan dan dimana waktu yang tepat untuk melakukan perbaikan terhadap kualitas.
Heizer dan Render (2006:265), menyatakan bahwa diagram ini disebut juga diagram tulang ikan (Fishbone Chart) dan berguna untuk memperlihatkan faktor-faktor utama yang berpengaruh pada kualitas dan mempunyai akibat pada masalah yang kita pelajari, selain itu kita juga dapat melihat faktorfaktor yang lebih terperinci yang berpengaruh dan mempunyai akibat pada faktor utama tersebut yang dapat kita lihat pada panah-panah yang berbentuk tulang ikan pada diagram fishbone tersebut. Prinsip yang digunakan untuk membuat diagram sebab akibat ini adalah sumbang saran atau brainstorming.

Faktor-faktor penyebab utama dalam diagram sebab akibat ini dapat dikelompokkan dalam : 1). Material (bahan baku); 2). Machine (mesin); 3). Man (tenaga kerja); 4). Method (metode); dan 5). Environment (lingkungan).

\section{PERUMUSAN HIPOTESIS}

Dalam memproduksi suatu produk, perusahaan telah menetapkan standar atas kualitas produk. Jika hasil produksinya dibawah standar kualitas produk maka terdapat produk gagal. Sehingga perlu adanya pengendalian kualitas supaya perusahaan dapat meminimumkan produk gagal. Menurut Ahyari (2000:240), pengendalian kualitas adalah merupakan suatu aktivitas (manajemen perusahaan) untuk menjaga dan mengarahkan agar kualitas produk (dan jasa) perusahaan dapat dipertahankan sebagaimana yang telah direncanakan.

Dalam Penelitian Darsono (2013) yang menyatakan metode Statistical Quality Control yang digunakan perusahaan dalam mengendalikan kualitas produk PT. Albata dapat menekan terjadinya kerusakan produk. Dan menurut penelitian lainnya menyatakan bahwa penerapan metode Statistical Quality Control dalam pengendalian kualitas produk $\mathrm{CV}$. Valentino Shoes dapat menekan jumlah kerusakan produk pada hasil produksi dengan menggunakan iagram pareto, peta kendali dan diagram tulang ikan oleh Dewi, Tasya dan Nining (2015). Serta menurut penelitian Hariastuti (2015) menyatakan pengendalian mutu produk dapat meminimalisasi kecacatan produk.

Berdasarkan uraian diatas, maka hipotesis yang dapat dikemukakan dalam penelitian ini adalah "diduga pengendalian kualitas produk menggunakan metode Statistical 
Quality Control (SQC) dapat meminimumkan produk gagal".

\section{KERANGKA PEMIKIRAN}

Perusahaan perlu memiliki pengendalian kualitas untuk menjamin agar hasilproduksinya sesuai dengan standar kualitas produk serta meminimumkan produk gagal. Kerangka pemikiran yang digunakan dalam penelitian ini adalah bagaimana pengendalian kualitas menggunakan metode Statistical Quality Control dapat meminimumkan produk gagal. Serta mengidentifikasi penyebab kegagalan produk dan memberikan solusi dan rekomendasi apa yang harus dilakukan oleh perusahaan.

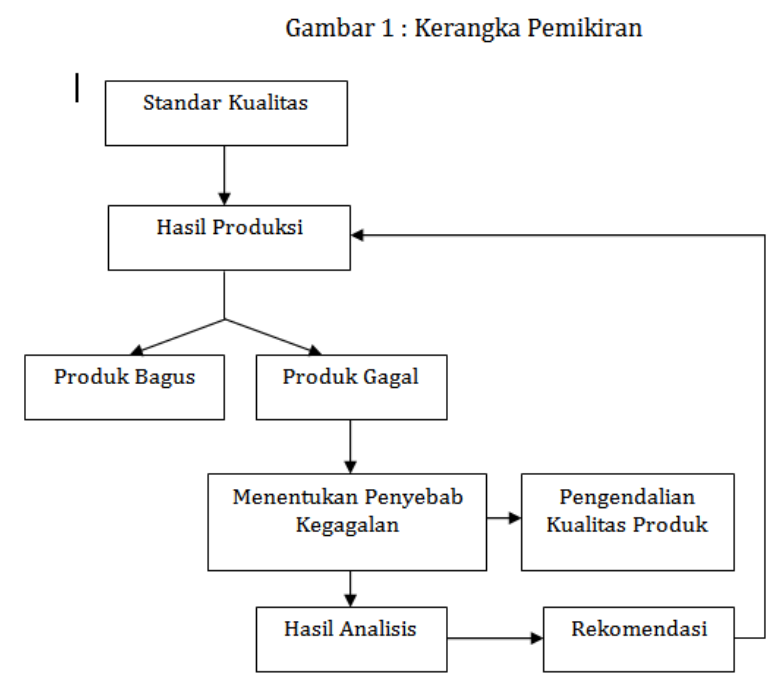

Sumber: Toko Roti Barokah Bakery, 2017

\section{METODE PENELITIAN}

\section{Jenis Penelitian}

Penelitian ini dilakukan pada usaha roti "Toko Roti Barokah Bakery" yang terletak di Jl. K.H. Abdul Aziz Gang 3 No.71 Kota Probolinggo. Lokasi penelitian tersebut dipilih secara sengaja dengan menggunakan data perusahaan dari bulan Januari sampai bulan Desember 2016.

Jenis dari penelitian yang digunakan peneliti adalah peneliatian deskriptif kuantitatif. Metode kuantitatif adalah metode penelitian berlandaskan filsafat positifme yang digunakan untuk meneliti pada populasi dan sampel tertentu dengan pengumpulan data menggunakan instrument penelitian, dan analisis data bersifat kuantitatif/statistik yang tujuan untuk menguji yang telah ditetapkan. (Sugiyono, 2013:12).

\section{Sumber Data}

Sumber data yang digunakan dalam penelitian ini yaitu data sekunder. Dimana Data sekunder diperoleh dari data hasil produksi yang berupa produk baik dan produk gagal dan dokumen-dokumen Toko Roti Barokah Bakery.

\section{METODE ANALISIS DATA}

Terkait dengan sifat penelitian ini yaitu menggambarkan secara deskriptif dan pengujian hipotesis dengan tahap-tahap sebagai berikut :

1. Tahap Pertama, Menghitung Prosentase Kerusakan

$$
p=\frac{n p}{n}
$$

Keterangan :

n $p \quad$ : jumlah gagal dalam sub grup

$\mathrm{n} \quad$ : jumlah yang diperiksa dalam sub grup

Subgrup : Hari ke-i

2. Tahap kedua, Menghitung garis pusat atau central line $(C L)$

Garis pusat merupakan rata-rata kerusakan produk $(p)$

$$
C L=p=\frac{n p}{n}
$$

Keterangan :

$\sum \mathrm{np} \quad$ : jumlah total yang rusak

$\sum \mathrm{n} \quad$ : jumlah total yang diperiksa

3. Tahap ketiga, Menghitung batas kendali atas atau Upper Control Limit (UCL) Untuk menghitung batas kendali atas atau UCL dilakukan dengan rumus :

$$
U C L=p=\sigma \frac{p 1-p}{n}
$$

Keterangan :

$$
\begin{aligned}
& p \quad \text { : rata-rata ketidak sesuaian } \\
& \text { produk } \\
& \mathrm{n} \quad: \text { jumlah produksi } \\
& \sigma \quad: 1,2,3
\end{aligned}
$$

4. Tahap keempat, Menghitung batas kendali bawah atau Lower Control Limit (LCL)

Untuk menghitung batas kendali bawah atau LCL dilakukan dengan rumus:

$$
L C L=p-\sigma \overline{\frac{p 1-p}{n}}
$$


Keterangan :

$\begin{array}{ll}p & : \text { rata-rata ketidak sesuaian } \\ \text { produk } & \\ \mathrm{n} & : \text { jumlah produksi } \\ \sigma & : 1,2,3\end{array}$

\section{HASIL PENELITIAN \\ Deskripsi Data}

Produk yang diperiksa dan Produk yang gagal Toko Roti Barokah Bakery

Tabel 1: Produk yang Piperiksa (Produk yang baik) Toko Roti Barokah
Bakery
\begin{tabular}{|c|l|c|c|c|c|c|}
\hline Tahun 2016 \\
\hline 1 & Bulan & Original & Keju & Coklat & Strawberry & Jumlah \\
\hline 1 & Januari & 500 & 450 & 600 & 460 & 2.010 \\
\hline 2 & Februari & 640 & 520 & 850 & 490 & 2.500 \\
\hline 3 & Maret & 620 & 620 & 850 & 510 & 2.600 \\
\hline 4 & April & 910 & 650 & 1.000 & 190 & 2.750 \\
\hline 5 & Mei & 250 & 550 & 750 & 650 & 2.200 \\
\hline 6 & Juni & 500 & 350 & 500 & 450 & 1.800 \\
\hline 7 & Juli & 450 & 375 & 500 & 425 & 1.750 \\
\hline 8 & Agustus & 550 & 400 & 600 & 500 & 2.050 \\
\hline 9 & September & 650 & 400 & 750 & 300 & 2.100 \\
\hline 10 & Oktober & 650 & 405 & 910 & 685 & 2.650 \\
\hline 11 & November & 750 & 650 & 900 & 600 & 2.900 \\
\hline 12 & Desember & 650 & 450 & 900 & 400 & 2.400 \\
\hline \multicolumn{7}{|c|}{ Total } \\
\hline \multicolumn{7}{|c|}{ Rata-rata } \\
\hline
\end{tabular}

Tabel 1 menunjukkan bahwa jumlah produk baik yang dilakukan di Toko Roti Barokah Bakery ini setiap bulannya tidaklah sama. Adapun rata-rata produksi per bulan 2.309 dengan total setiap tahunnya 27.710 .

\begin{tabular}{l} 
Tabel 2: Produk gagal Toko Roti Barokah Bakery \\
\begin{tabular}{|c|l|c|c|c|c|c}
\hline No & Bulan & Original & Keju & Coklat & Strawberry & Jumlah \\
\hline 1 & Januari & 60 & 50 & 90 & 50 & 250 \\
\hline 2 & Februari & 60 & 60 & 110 & 40 & 270 \\
\hline 3 & Maret & 90 & 60 & 100 & 40 & 290 \\
\hline 4 & April & 120 & 70 & 90 & 20 & 300 \\
\hline 5 & Mei & 60 & 50 & 60 & 30 & 200 \\
\hline 6 & Juni & 45 & 30 & 50 & 50 & 175 \\
\hline 7 & Juli & 40 & 30 & 50 & 30 & 150 \\
\hline 8 & Agustus & 50 & 40 & 60 & 60 & 200 \\
\hline 9 & September & 55 & 40 & 65 & 30 & 190 \\
\hline 10 & Oktober & 75 & 45 & 80 & 65 & 265 \\
\hline 11 & November & 60 & 50 & 70 & 20 & 200 \\
\hline 12 & Desember & 75 & 60 & 100 & 20 & 255 \\
\hline \multicolumn{7}{|c|}{ Total } \\
\hline \multicolumn{7}{|c|}{ Rata-rata } \\
\hline
\end{tabular} Sumber: Data Sekunder Toko Roti Barokah Bakery, 2017 \\
\hline
\end{tabular}

Tabel 2 menunjukkan bahwa jumlah produk gagal yang dilakukan di Toko Roti Barokah Bakery ini setiap bulannya tidaklah sama. Adapun rata-rata produksi produk gagal per bulan 229 dengan total setiap tahunnya produk gagal yang dialami Toko Roti Barokah Bakery sebanyak 2.745 .
Gambar 2 Diagram Pareto Berdasarkan Jenis Kesalahan pada Produksi Tahun 2016

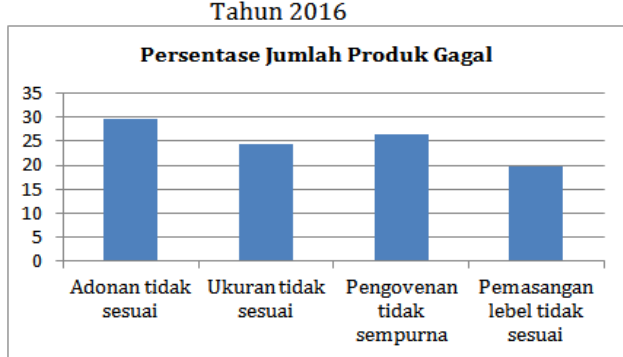

Sumber Data: Data Diolah, 2016

Tabel 3 menunjukkan jumlah produksi yang dilakukan Toko Roti Barokah Bakery setiap bulanyya tidaklah sama. Hal tersebut dikarenakan dalam menentukan jumlah produk yang akan diproduksi oleh Toko Roti Barokah Bakery didasarkan pada order yang diterima. Adapun rata-rata produksi per bulan 2.309 biji dengan rata-rata produk gagal sebesar 229 biji atau sekitar 9,9125\% dari total produksi setiap bulan.

Tabel 3 : Data Jumlah Produksi dan Produk Gagal Toko Roti Barokah Bakery
\begin{tabular}{|c|l|c|c|c|}
\hline NO & Bulan & Produk Baik & $\begin{array}{c}\text { Produk } \\
\text { Gagal }\end{array}$ & $\begin{array}{c}\text { Persentase } \\
(\%)\end{array}$ \\
\hline 1 & Januari & 2.010 & 250 & $12,4 \%$ \\
\hline 2 & Februari & 2.500 & 270 & $10,8 \%$ \\
\hline 3 & Maret & 2.600 & 290 & $11,15 \%$ \\
\hline 4 & April & 2.750 & 300 & $10,9 \%$ \\
\hline 5 & Mei & 2.200 & 200 & $9 \%$ \\
\hline 6 & Juni & 1.800 & 175 & $9,7 \%$ \\
\hline 7 & Juli & 1.750 & 150 & $8,6 \%$ \\
\hline 8 & Agustus & 2.050 & 200 & $9,6 \%$ \\
\hline 9 & September & 2.100 & 190 & $9 \%$ \\
\hline 10 & Oktober & 2.650 & 265 & $10,3 \%$ \\
\hline 11 & November & 2.900 & 200 & $6,9 \%$ \\
\hline 12 & Desember & 2.400 & 255 & $10,6 \%$ \\
\hline \multicolumn{7}{|c|}{ Total } & $\mathbf{2 7 . 7 1 0}$ & $\mathbf{2 . 7 4 5}$ & 118.95 \\
\hline Rata-rata & $\mathbf{2 3 0 9}$ & $\mathbf{2 2 9}$ & 9,9125 \\
\hline
\end{tabular}
Sumber: data diolah, 2017

\section{Menentukan Prioritas Perbaikan (Diagram} Pareto)

Untuk mengindentifikasi kesalahankesalahan yang dominan dalam proses produksi roti yang dilakukan oleh "Barokah Bakery" dapat diketahui melalui diagram pareto. Diagram Pareto adalah grafik batang yang menunjukkan masalah berdasarkan urutan banyaknya kejadian.

Tabel 4 menunjukkan bahwa karakteristik kualitas yang terbanyak menghasilkan produk cacat selama periode tahun 2016 adalah jenis proses produk atau adonan tidak sesuai (tidak jadi) yaitu sebanyak 810 satuan atau sebesar $29,5 \%$. Untuk lebih jelasnya jenis kesalahan per departemen adalah sebagai berikut :

Berdasarkan Gambar 2 dapat dilihat bahwa produk gagal yang terjadi pada proses produksi cenderung didominasi oleh proses produk atau adonan tidak sesuai dengan persentase kerusakan mencapai $29,5 \%$ dari total produk gagal. Kondisi ini mencerminkan bahwa 
proses pengendalian yang dilakukan perlu dioptimalkan mengingat proses produk atau adonan tidak sesuai akan mengurangi kuantitas yang di jual dan kualitas hasil produksi yang nantinya akan berdampak pada keuntungan perusahaan.

\section{Peta Kendali (Control Chart)}

Inti pengendalian mutu adalah penggunaan metode statistik untuk mengambil keputusan. Salah satu metode statistik yang dapat digunakan untuk pengendalian adalah peta kendali $p$. Peta kendalipadalah suatu alat yang secara grafis digunakan untuk memonitor dan mengevaluasi apakah suatu aktivitas atau proses berada dalam pengendalian kualitas secara statistika atau tidak sehingga dapat memecahkan masalah dan menghasilkan

Tabel 4 : Data Jenis Cacat, jumlah Cacat dan Persentase Cacat Pada Produk

\begin{tabular}{|c|c|c|}
\hline \multicolumn{3}{|l|}{ Roti } \\
\hline Jenis Cacat & $\begin{array}{c}\text { Jumlah } \\
\text { Cacat (biji) }\end{array}$ & $\begin{array}{c}\% \\
\text { cacat }\end{array}$ \\
\hline $\begin{array}{l}\text { Proses Produk atauadonan tidak sesuai (tidak } \\
\text { jadi) }\end{array}$ & 810 & $\begin{array}{c}29,5 \\
\%\end{array}$ \\
\hline Pengovenan tidak sempurna & 720675 & $26,3 \%$ \\
\hline Bentuk dan ukura tidak sesuai & 675 & $24,5 \%$ \\
\hline Pemasangan lebel tidak sesuai & 540 & $\begin{array}{c}19,7 \\
\%\end{array}$ \\
\hline Jumlah & 2.745 & $\begin{array}{c}100 \\
\%\end{array}$ \\
\hline
\end{tabular}

perbaikan kualitas. Bentuk dasar bagan atau grafik pengendali merupakan peragaan grafik suatu karakteristik kualitas yang telah diukur atau dihitung dari sampel terhadap nomor sampel atau waktu. Grafik ini memuat garis tengah yang merupakan nilai rata-rata karakteristik kualitas yang berkaitan dengan keadaan yang terkendali (CL).Dua garis mendatar dinamakan garis pengendali atas (UCL) dan batas pengendali bawah (LCL).Adapun tahap-tahap untuk

Keterangan :

$\sum$ np : jumlah total yang rusak

$\sum \mathrm{n} \quad$ : jumlah total yang diperiksa

$$
C L=p=\frac{n p}{n}
$$

$$
=\underline{2.745}
$$

27.710

$=0,099$

c. Dan tahap ketiga menghitung batas membuat peta kendali ptersebut adalah :

a. Tahap pertama yang dilakukan adalah menghitung persentase kerusakan produk dengan rumus :

$$
p=\frac{n p}{n}
$$

Keterangan :

n $p$ : jumlah gagal dalam sub grup

$\mathrm{n} \quad$ : jumlah yang diperiksa dalam sub grup

Subgrup : Hari ke-i

TTabel 5

Persentase kerusakan produk

\begin{tabular}{|l|c|c|c|}
\hline \multicolumn{5}{|c|}{ Persentase kerusakan produk } \\
\hline Banuari & Jumlah Gagal & $\begin{array}{c}\text { Jumlah yang } \\
\text { diperiksa }\end{array}$ & Jumlah \\
\hline Februari & 250 & 2.010 & $0,124 \%$ \\
\hline Maret & 270 & 2.500 & $0,108 \%$ \\
\hline April & 290 & 2.600 & $0,111 \%$ \\
\hline Mei & 300 & 2.750 & $0,109 \%$ \\
\hline Juni & 200 & 2.200 & $0,090 \%$ \\
\hline Juli & 175 & 1.800 & $0.097 \%$ \\
\hline $\begin{array}{l}\text { Agustu } \\
\text { s }\end{array}$ & 150 & 1.750 & $0,085 \%$ \\
\hline September & 200 & 2.050 & $0,097 \%$ \\
\hline $\begin{array}{l}\text { Oktobe } \\
\text { r }\end{array}$ & 190 & 2.100 & $0,090 \%$ \\
\hline November & 205 & 2.650 & $0,1 \%$ \\
\hline Desember & 255 & 2.900 & $0,068 \%$ \\
\hline
\end{tabular}

Sumber: data diolah, 2017

b. Kemudian tahap kedua yaitu menghitung garis pusat atau central line (CL)

Garis pusat merupakan rata-rata kerusakan produk $(p)$

$$
C L=p=\frac{n p}{n}
$$

kendali atas atau Upper Control

Limit(UCL)

Untuk menghitung batas kendali atas atau UCL dilakukan dengan rumus :

$$
U C L=p+\sigma \frac{p 1-p}{n}
$$

Keterangan :

$$
\begin{aligned}
& p \quad: \text { rata-rata ketidak sesuaian } \\
& \text { produk } \\
& \mathrm{n} \quad: \text { jumlah produksi } \\
& \sigma \quad: 1,2,3
\end{aligned}
$$




$$
\begin{aligned}
& U C L=p+\sigma \frac{\overline{p 1-p}}{n}=0,099+ \\
& 3 \frac{\overline{0,0991-0,099}}{27.710}=0,099+ \\
& 3 \overline{0,005702}=0,1161
\end{aligned}
$$

d. Tahap keempat yaitu menghitung batas kendali bawah atau Lower Control Limit (LCL)

$$
\begin{aligned}
& \begin{array}{r}
\text { Keterangan : } \\
p \quad: \text { rata-rata ketidak sesuaian produk } \\
\mathrm{n} \quad: \text { jumlah produksi } \\
\sigma \quad
\end{array} \\
& L C L=p-\sigma \frac{\frac{p 1,2,3}{n}}{\frac{0,0991-0,099}{27.710}} \\
& =0,099-3 \frac{0}{0,005702} \\
& =0,099-3 \quad \\
& =0,0819
\end{aligned}
$$

\section{Diagram Tulang Ikan (Fishbone Chart)}

Diagram sebab akibat memperlihatkan hubungan antara permasalahan yang dihadapi dengan kemungkinan penyebabnya serta faktor-faktor yang mempengaruhinya.Setelah diketahui jenisjenis kesalahan yang terjadi, maka Toko Roti Barokah Bakery perlu mengambil langkah-langkah perbaikan untuk mencegah timbulnya kerusakan yang serupa. Hal penting yang harus dilakukan dan ditelusuri adalah mencari penyebab timbulnya kerusakan tersebut. Sebagai alat bantu untuk mencari penyebab terjadinya kesalahan tersebut, digunakan diagram sebab akibat atau yang disebut fishbone chart. Adapun penggunaan diagram sebab akibat untuk menelusuri jenis masingmasing kesalahan yang terjadi.

Berdasarkan diagram pareto telah diketahui empat jenis cacat pada proses produksi roti. Jenis-jenis cacat tersebut antara lain adalah:

a. Proses Produk atau adonan tidak sesuai (tidak jadi);

b. Bentuk dan ukuran tidak sesuai;

c. Pengovenan tidak sempurna;

d. Pemasangan lebel tidak sesuai.
Untuk menghitung batas kendali bawah atau LCL dilakukan dengan rumus:

$$
L C L=p-\sigma \overline{\frac{p 1-p}{n}}
$$

\begin{abstract}
Berdasarkan analisa diagram sebab akibat, bahwa masalah kegagalan produksi roti cenderung lebih banyak diakibatkan oleh faktor manusia dibandingkan dengan faktor lainnya. Supaya produk yang dihasilkan berkualitas dan rendahnya kegagalan dalam proses produksi dikarenakan produk yang gagal paling banyak yaitu adonan yang tidak sesuai, maka perusahaan perlu melakukan pelatihan bagi karyawan baru sebelum mereka siap untuk bekerja sesuai dengan standar perusahaan serta melakukan penyesuaian terkait dengan kesejahteraan karyawan yang bertujuan untuk menanggulangi kegagalan pada proses produksi guna memajukan perusahaan. Selain itu pula perbaikan dalam kualitas tenaga kerja diharapkan mampu mengoptimalkan proses produksi dan mengurangi terjadainya kegagalan proses produksi yang diakibatkan oleh faktor bahan baku, mesin, metode atau cara kerja serta lingkungan, mengingat manusia merupakan penggerak dari input lain dalam kegiatan proses produksi yang terjadi dalam perusahaan.
\end{abstract}

\section{PEMBAHASAN}

Perumusan hipotesis yang diusulkan pada penelitian ini yaitu: "diduga pengendalian kualitas produk menggunakan metode Statistical Quality Control (SQC) dapat meminimumkan produk gagal".

Setelah melakukan analisis Control Chart untuk Toko Roti Barokah Bakery yang telah dijelaskan pada hasil penelitian diatas, dapat diketahui yaitu jumlah produk yang di periksa sebanyak 27.710 unit dari hasil produksi yang dilakukan oleh perusahaan. Dan rata-rata kerusakan produk sebesar 0,099 atau 9,9\%. 
Untuk batasan pengawasan atau pengendalian kualitas pada perusahaan yaitu batas atas (UCL) sebesar 0,1161 atau $11,61 \%$ dan batas bawah (LCL) sebesar 0,0819 atau 8,12\%.

Dapat dikatakan bahwa pengendalian kualitas terhadap Toko Roti Bakery sudah baik, karena jumlah produk gagal masih dalam batas wajar yaitu terletak antara batas atas dan batas bawah. Setelah melakukan analisis diagram sebab akibat, dapat diketahui bahwa faktor utama penyebab terjadinya kegagalan produk dikarenakan kelalaian manusia atau faktor sumber daya manusia. Untuk itu perlu diadakan pelatihan terhadap sumber daya manusia yang digunakan.

Dari hasil pembahasan diatas disimpulkan bahwa dengan menggunakan metode Statistical Quality Control (SQC) dalam pengendalian kualitas dapat meminimumkan produk gagal. Hali ini juga menjawab hipotesis dalam penelitian ini yang sudah tercantum diatas, dan merekomendasikan metode SQC dengan tekhnik control chart dan diagram sebab akibat untuk dijadikan bahan pertimbangan dalam pengendalian kualitas pada Toko Roti Barokah Bakery. Hasil ini juga didukung oleh penelitian sebelumnya Darsono (2013), penelitian Dewi, Tasya dan Nining (2015) dan penelitian Hariastuti (2015) yang menyatakan pengendalian kualitas dengan menggunakan metode Statistical Quality Control (SQC) dapat meminimumkan produk gagal. Oleh karena itu, Penelitian ini konsisiten dengan penelitian-penelitian sebelumnya yang membuktikan bahwa pengendalian kualitas dengan menggunakan metode Statistical Quality Control (SQC) memang dapat meminimumkan produk gagal.

\section{KESIMPULAN}

Hasil penelitian dan analisis pada Toko Roti Barokah Bakery dapat disimpulkan sebagai berikut:

1. Jumlah produk baik yang dihasilkan oleh Toko Roti Bakery sebanyak 27.710 unit. Dan dengan menganalisis menggunakan Control Chart, rata-rata kerusakan produk sebesar 0,099 atau 9,9\%. Dan rata-rata kerusakan produk tersebut terdapat diantara batas atas yaitu sebesar 0,1161 atau $11,61 \%$ dan batas bawah sebesar 0,0819 atau $8,12 \%$. Itu menandakan bahwa tingkat kerusakan produk masih dalam batas wajar.

2. Dengan menggunakan diagram sebab akibat, dapat diketahui bahwa faktor utama penyebab terjadinya kegagalan produk adalah faktor manusia. Sehingga perlu diadakan pelatihan terhadap tenaga kerja supaya dapat meminimalkan produk gagal pada hasil produksi.

\section{SARAN}

Adapun saran yang dikemukakan adalah sebagai berikut:

1. Untuk masa yang akan datang sebaiknya Toko Roti Barokah Bakery menerapkan metode SQC dalam mengendalikan kualitas sehingga perusahaan dapat meminumkan produk gagal dari hasil produksi.

2. Diagram sebab akibat dapat digunakan untuk mengetahui faktor-faktor penyebab terjadinya produk gagal dari hasil produksi dan juga dapat mengetahui penyebab utama. Sehingga perlu digunakan diagram sebab akibat untuk mengetahui penyebab terjadinya kegagalan suatu produk.

\section{DAFTAR PUSTAKA}

Ahyari, Agus. 2000. Manajemen Produksi. BPFEUGM. Yogyakarta.

Assauri, Sofjan. 2004. Manajemen Produksi dan Operasi. LPFE - UI. Edisi Revisi. Jakarta

Darsono. 2013. Analisis Pengendalian Kualitas Produksi dalam Upaya Mengendalikan Tingkat kerusakan Produk. Jurnal Ekonomi-ManajemenAkuntansi No. 35/ Th. XX/ Oktober 2013. ISSN:0853-8778

Dewi, Tasya dan Nining. 2015. Analisis Pengendalian Kualitas dengan Menggunakan Metode Statistical Quality Control (SQC) Produk Sepatu Untuk Meminimumkan Produk Cacat (Studi Kasus Pada CV. Valentino Shoes Kabupaten Bandung). Prosiding Manajemen ISSN:24606545.

Hariastuti, Ni Luh Putu. 2015. Analisis Pengendalian Mutu Produk Guna Meminimalisasi Produk Cacat. Seminar Nasional IENACO-2015. ISSN:2337-4349.

Heizer, Jay \& Render, Barry. 2006. Operations Management (Manajemen Operasi). Salemba Empat. Jakarta.

Russell, Roberta \& Taylor, Bernard W. 2006. Operations Management. $5^{\text {th }}$ Edition. John Wiley \& Sons.

Sugiyono. 2013. Metode Penelitian Bisnis. Alfabeta. Bandung.

Yamit, Zulian. 2013. Manajemen Kualitas Produk \& Jasa. Ekosinia. Jakarta. 